\title{
UNDERNUTRITION IN THE TREATMENT OF CORONARY ARTERY DISEASE (PARTICULARLY THROMBOSIS). EFFECT ON THE BASAL METABOLISM AND CIRCULATION ${ }^{1}$
}

\author{
By A. M. MASTER, H. L. JAFFE, AND S. DACK \\ (From the Medical Services and the Cardiographic Laboratory, The Mount Sinai Hospital, \\ New York)
}

(Received for publication February 11, 1936)

A low calorie diet in the treatment of coronary thrombosis has been systematically used by one of us for a number of years with good results (1). Assuming that the observations made by Benedict et al. (2), Lusk (3) and Du Bois (4) in normal people were applicable to those with acute heart disease it was thought that the beneficial results obtained could be attributed in part to the lowering of the basal metabolic rate and decrease in the work of the heart which such a diet would effect. An intensive investigation was therefore undertaken two years ago, and the results in eight patients have already been reported (5). We have now extended our studies to a larger series and are presenting our findings in forty-two patients (Table I).

\section{METHOD}

Twenty-nine of the patients in this series were in the hospital wards with acute coronary artery thrombosis. The remainder were ambulatory and suffering from angina pectoris with or without a history of previous coronary occlusion. The former were kept in bed for four to six weeks, longer if necessary. All were placed on a diet of approximately 800 calories (1) consisting of 80 grams of carbohydrate, 50 grams of protein and 30 grams of fat. This diet is well balanced and calculated to supply an adequate amount of vitamins and minerals.

Fluids were moderately restricted, 1200 to 1500 cc. being allowed unless heart failure was present. Only in the latter condition was salt limited.

The low calorie diet was always maintained beyond the acute phase of the thrombosis, usually three months. The patient was then given graduated diets of 1200,1500 and 2000 or more calories for adequate periods of time. Following

${ }^{1}$ This study was made possible by grants from Mr. $\mathrm{H}$. H. Lehman, Mrs. Charles Altschul and Mr. Frank Altschul. any of these periods the diet was often again reduced to 800 calories for comparison with the initial period.

To determine the effect of the 800 calorie diet on the basal metabolic rate, it was essential to have, as a control, accurate figures while the patient was on a regular diet. We attempted to obtain these by taking readings soon after admission to the hospital but when, as frequently happened, the seriousness of the conditions made this impossible, the control figures were determined after a regular diet had been resumed. In thirteen patients " normal" figures were obtained both at the beginning and at the end of the experiment, the results coinciding. With the ambulatory patients, control readings were usually obtained before the 800 calorie diet was instituted and while the patient was still on his regular diet.

\section{RESULTS}

A drop of 15 per cent or more in basal metabolic rate was considered a significant effect of the low calorie diet on basal metabolism. Of the 42 cases studied, this result was obtained in 31 ( 74 per cent) and these we have designated successes. Six were only partially successful, that is, the basal metabolic rate fell 10 to 14 per cent. In five, considered failures, the drop was less than 10 per cent. Our results are recorded completely in Table I, which is arranged according to initial weight and includes age, sex, height, weight at the onset and the end of the diet, ideal weight, ${ }^{2}$ basal metabolic rate and oxygen consumption at various levels of diet. In addition, seven cases have been chosen for graphic presentation (Figures 1 to 8 ).

2 As obtained from Medico-Actuarial Mortality Investigation, Vol. 1, 1912, New York Association of Life Insurance Medical Directors and Actuarial Society of America. 


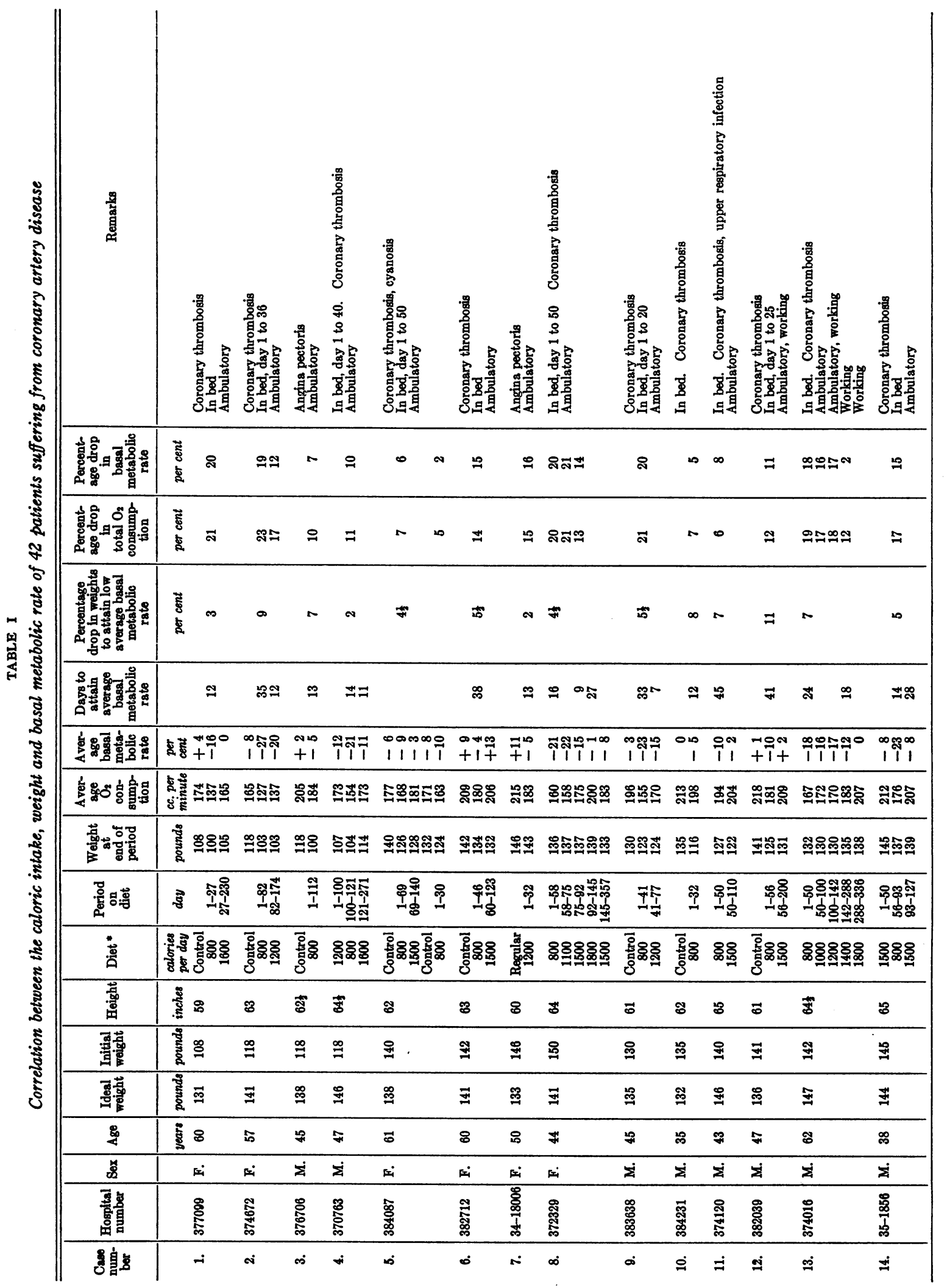




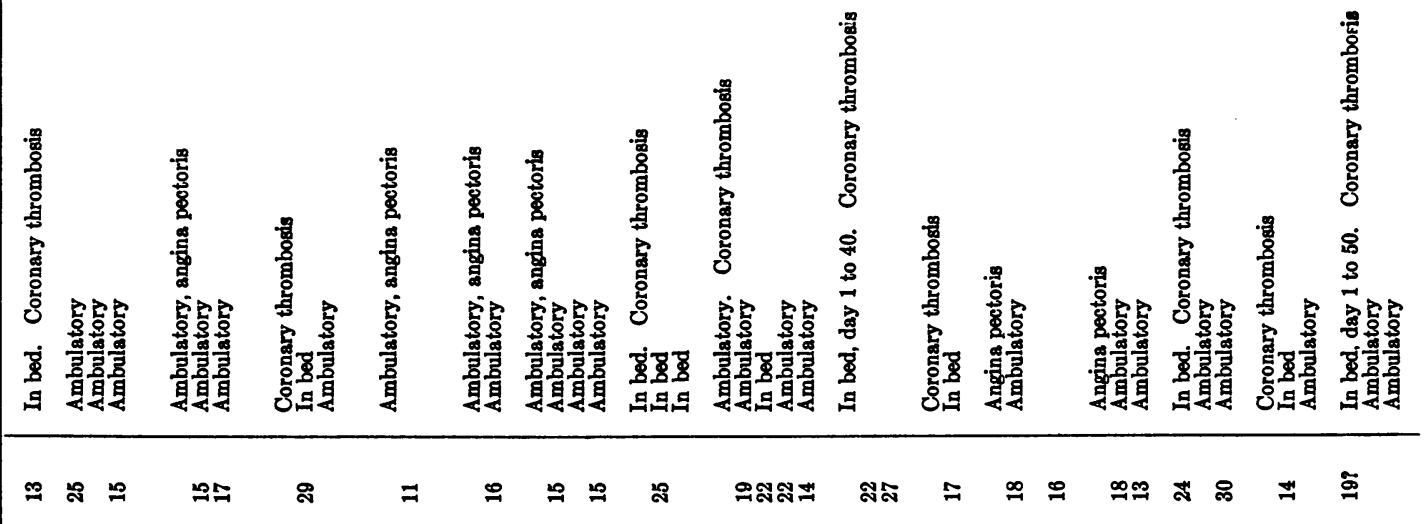

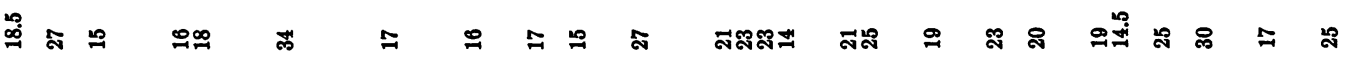

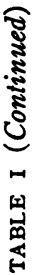

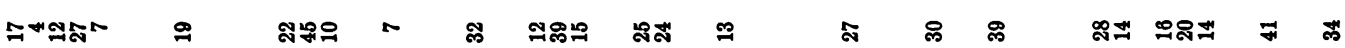

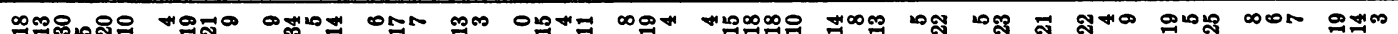

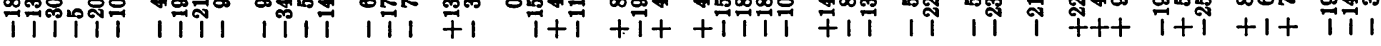

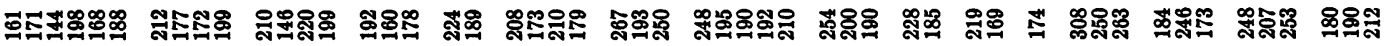

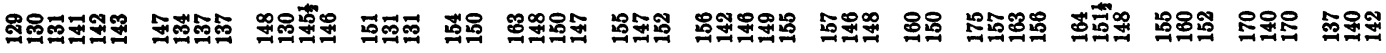



ి

\begin{tabular}{|c|c|c|c|c|c|c|c|c|c|c|c|c|c|c|}
\hline$\ddot{8}$ & 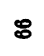 & $\Phi$ & $\tilde{0}$ & 8 & § & $\approx$ & పे & $\tilde{\sigma}$ & $\tilde{0}$ & $\ddot{0}$ & $\Phi$ & $\$$ & 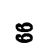 & $\tilde{0}$ \\
\hline 9 & $\Xi$ & $\stackrel{9}{=}$ & $\overrightarrow{\underline{D}}$ & 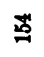 & $\stackrel{8}{\square}$ & $\stackrel{2}{\stackrel{2}{2}}$ & $\stackrel{0}{\sharp}$ & 홍 & 8 & 옥 & 苛 & $\stackrel{\rightleftarrows}{\stackrel{0}{0}}$ & $\stackrel{8}{1}$ & $\stackrel{9}{I}$ \\
\hline : & 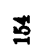 & $\vec{\Xi}$ & 听 & 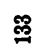 & 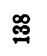 & $\underset{\boldsymbol{\Phi}}{\vec{D}}$ & 욤 & $\stackrel{9}{\stackrel{9}{9}}$ & 兽 & 9 & ซี & I & $\stackrel{20}{9}$ & 匍 \\
\hline 8 & เ8 & 아 & 29 & $\overrightarrow{\text { is }}$ & $\stackrel{80}{\circ}$ & ชี & 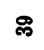 & $\approx$ & $\Re$ & $\mathscr{8}$ & 趈 & 8 & is & $\overrightarrow{50}$ \\
\hline$\dot{x}$ & $\dot{\Sigma}$ & $\dot{\Sigma}$ & \&i & si & 8 & $\dot{\Sigma}$ & $\dot{\Sigma}$ & $\dot{\Sigma}$ & $\dot{\Sigma}$ & $\dot{\Sigma}$ & $\dot{\Sigma}$ & $\dot{\Sigma}$ & $\dot{\Sigma}$ & $\dot{\Sigma}$ \\
\hline 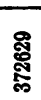 & $\underset{\stackrel{\infty}{\Phi}}{\vec{\Phi}}$ & 宮 &  & 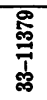 & 勇 & 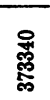 &  & $\underset{\text { 岕 }}{\vec{\Xi}}$ & 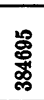 & 芯 & 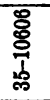 & 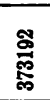 & 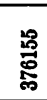 & 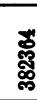 \\
\hline هُ & $\dot{\Phi}$ & $\therefore$ & $\stackrel{\infty}{\sim}$ & $\stackrel{\Delta}{ }$ & สุ่ & $\dot{\vec{a}}$ & สี่ & ঞ̊ & ذ่ & ฉึ่ & هั & $\dot{\mathrm{a}}$ & $\stackrel{\infty}{\circ}$ & ภุ่ \\
\hline
\end{tabular}




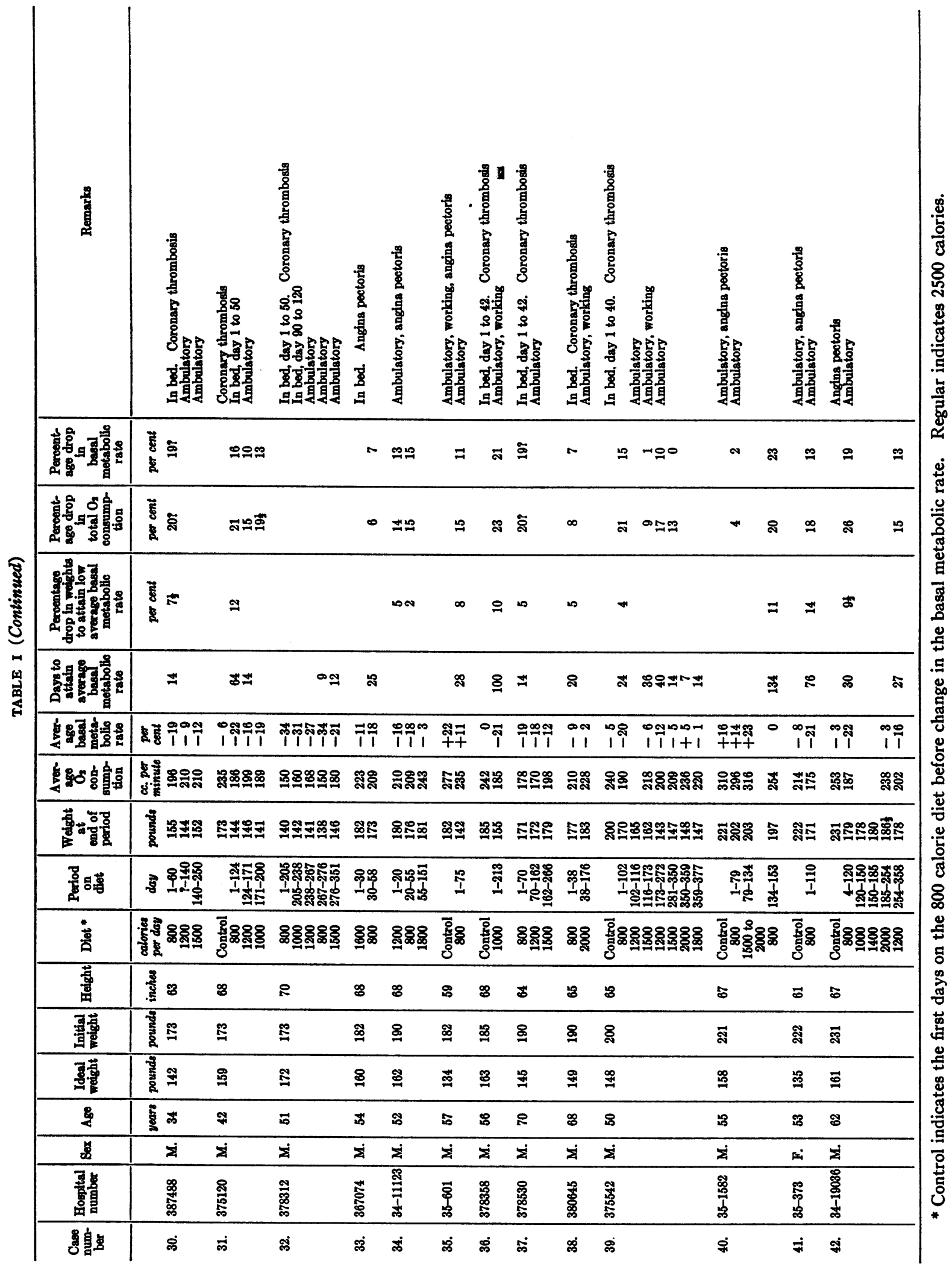


It will be seen that the control basal metabolic rate varied between +10 and -10 in 83 per cent of the cases. The average in the different weight groups did not vary essentially; neither leanness nor obesity was associated with a characteristic basal metabolism (6).

The drop in metabolism on the 800 calorie diet was sufficient to permit maintenance of the pa-

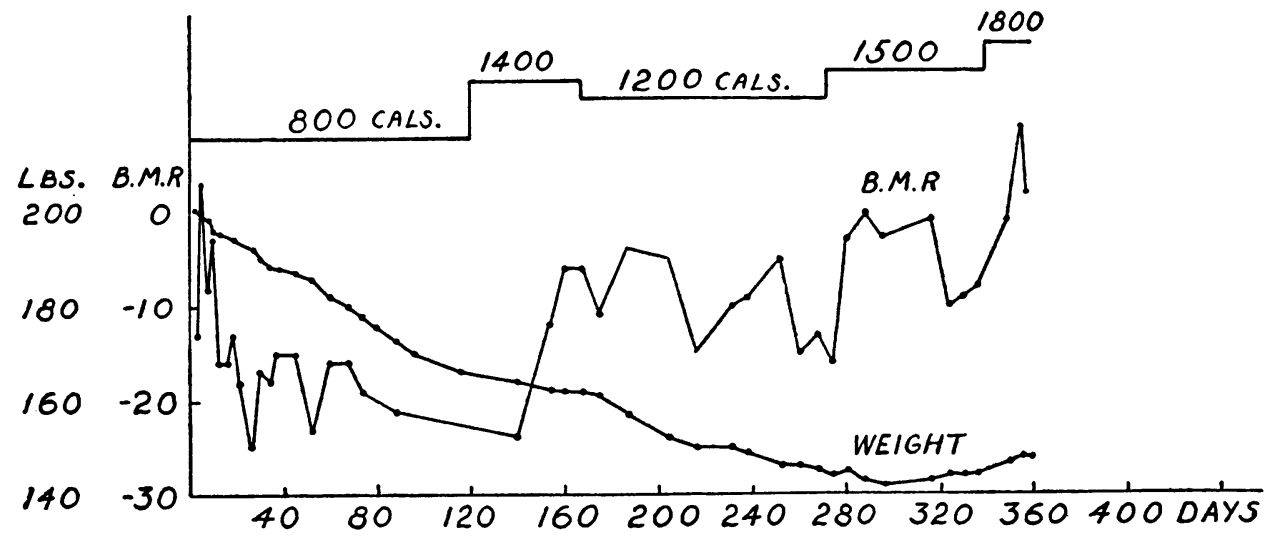

Fig. 1. Correlation between Diet, Weight and Basal Metabolic Rate in Case 39, Male, AGE 50.

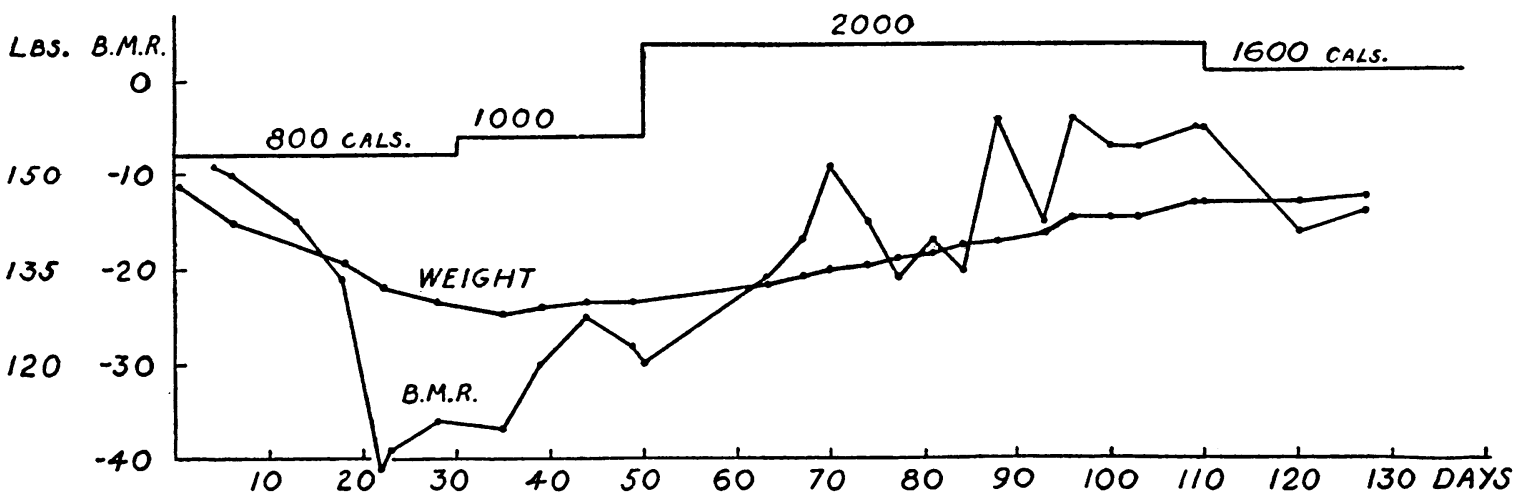

Fig. 2. Correlation between Diet, Weight and Basal Metabolism in Case 17, Male, Age 40.



Fig. 3. Correlation between Diet, Weight and Basal Metabolism in Case 2, Female, Age 57. 
tients at a basal metabolic level of -20 per cent, or lower. In 22 of the cases the average drop in the basal metabolic rate was 15 to 20 per cent; in 9 it was 21 to 35 per cent. In the latter group a rate of -40 was reached in 2 cases, and -30 in 2 others. The fall in basal metabolic rate was of course found to parallel that in oxygen consumption. However, when a considerable loss in weight occurred, because of the changes in body surface, the basal metabolic rate did not adequately reflect the actual drop in basal metabolism. Thus in Case 31, after a loss of twenty-nine pounds, or 17 per cent of the initial body weight, a drop of 21 per cent in oxygen consumption was equivalent to a fall of only 16 per cent in basal metabolic rate.



Fig. 4. Correlation between Diet, Weight and Basal Metabolism in Case 31, Male, AGE 42.

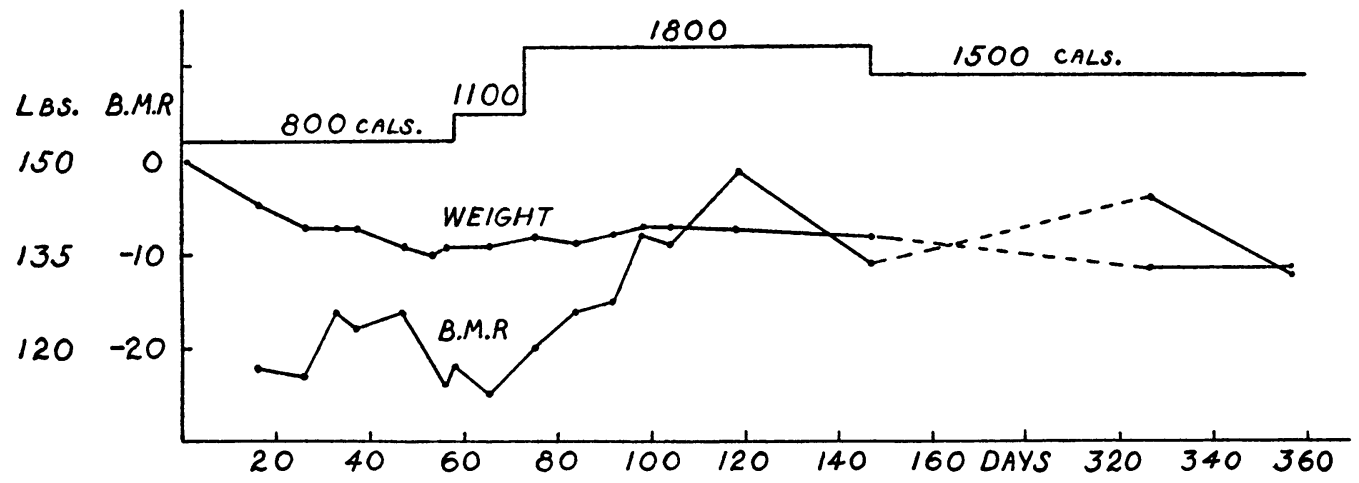

Fig. 5. Correlation between Diet, Weight and Basal Metabolism in Case 8, Female, Age 44.

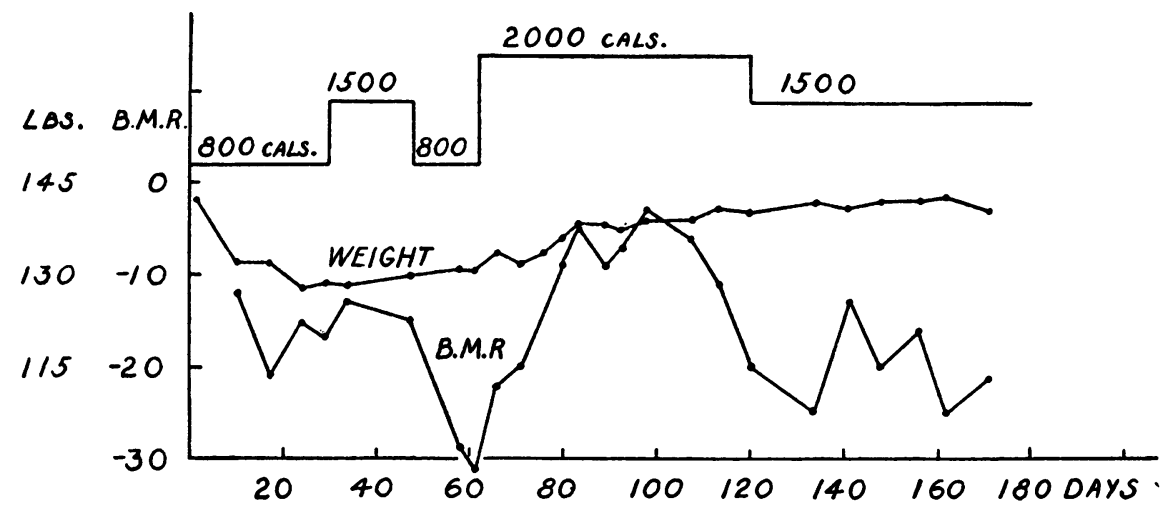

Fig. 6. Correlation between Diet, Weight and Basal Metabolism in Case 15, Male, Age 59. 
Time of drop in basal metabolic rate

Following the institution of an 800 calorie diet the basal metabolic rate reached the low levels in an average of two to four weeks. When the diet was increased a rise in the rate did not occur until a similar period had elapsed. Despite a marked change in diet, therefore, the metabolism of the body is determined for several weeks by the previ- given an 800 calorie diet, and the basal metabolic rates dropped to their previous low levels or even lower, and usually more rapidly than in the first instance. For example, in Case 15 (Figure 6), the basal metabolic rate on an 800 calorie diet fell to -21 per cent on the seventeenth day. On a 1500 calorie diet it rose to -7 per cent in ten days. When an 800 calorie diet was resumed, the

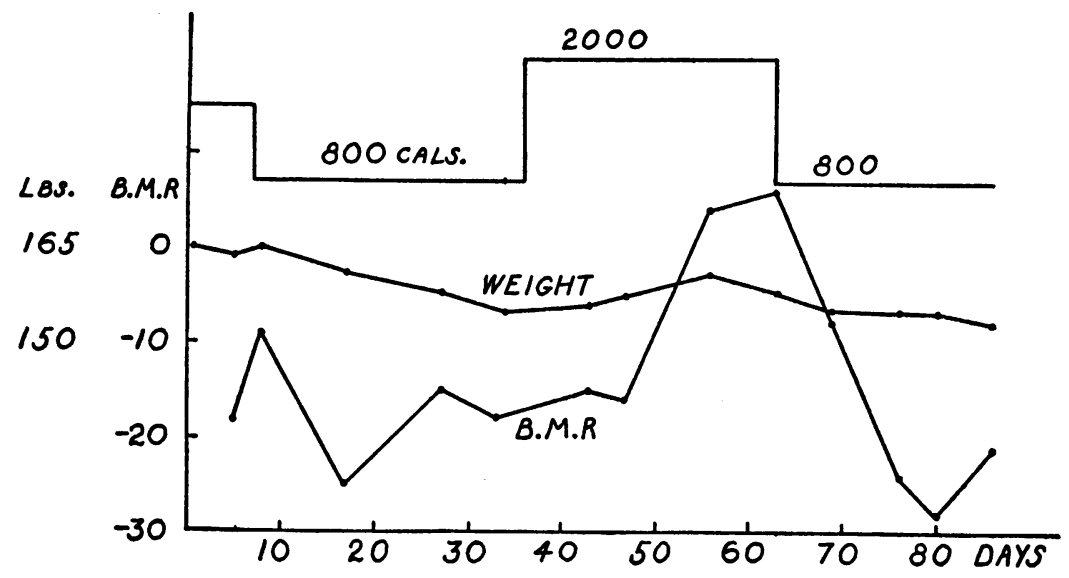

Fig. 7. Correlation between Diet, Weight and Basal Metabolism in Case 27, Male, Age 50.

ous state of nutrition. In other words, if an 800 calorie diet has been taken for some time, a sudden increase even to 3000 calories daily for several days, will not influence the basal metabolism. Anderson and Lusk (7) reported similar findings.

A change in caloric intake eventually was associated with a distinctive change in basal metabolic rate. Certain levels of basal metabolism were usually established by varying caloric intakes, i.e., $800,1200,1500$ or 2000 . Thus if the basal metabolic rate had fallen to -20 on an 800 calorie diet (Case 39, Figure 1), it rose to -12 on a 1200 calorie diet, and to -6 on a 1500 calorie diet and on a 2000 calorie diet became +5 . (See Figures 1 to 7 and Table I.) Not infrequently, there was no difference in effect between an 800 and a 1200 calorie diet (Case 16 and 32), and it was only after a regular diet had been resumed (2000 calories or more) that the basal metabolic rate returned to normal.

\section{Repeated drops in basal metabolic rate}

Following the return to a regular diet several patients (Cases 15, 20, 27, 39, 42) were again rate fell to -29 per cent, in eleven days. This more profound and more rapid effect was probably the result not only of the improved clinical condition of the patient but also of the previous undernutrition with the consequent depletion of excess body fat.

\section{Factor of weight}

The drop in basal metabolic rate on the low calorie diet is obviously closely related to loss of weight. Indeed it might be expected that the decrease in basal rate merely reflected the degree and course of the weight loss. Richardson and Mason (8) observed that in diabetics treated with a low calorie diet the greater the loss of weight the lower the basal metabolic rate. However, our studies revealed some interesting deviations from this view.

The relation of loss of weight to drop in basal metabolic rate for various weight groups is presented in Table II. It will be seen that the results were fairly uniform for all weights below 200 pounds: the average drop in basal metabolic rate was 15.5 to 17 per cent; the loss of weight neces- 
TABLE II

Correlation of initial and ideal weight with loss of weight and fall in basal metabolic rate

\begin{tabular}{|c|c|c|c|c|c|c|c|}
\hline \multirow[t]{2}{*}{$\begin{array}{l}\text { Initial } \\
\text { weight }\end{array}$} & \multirow[t]{2}{*}{$\begin{array}{c}\text { Num- } \\
\text { ber } \\
\text { of } \\
\text { cases }\end{array}$} & \multicolumn{2}{|c|}{$\begin{array}{c}\text { Number } \\
\text { of } \\
\text { succesful }\end{array}$} & \multicolumn{2}{|c|}{$\begin{array}{c}\text { Percentage loss } \\
\text { of initial weight } \\
\text { necessary to } \\
\text { obtain low } \\
\text { basal metabolic } \\
\text { rate level }\end{array}$} & \multicolumn{2}{|c|}{$\begin{array}{l}\text { Percentage } \\
\text { drop in } \\
\text { average } \\
\text { basal } \\
\text { metabolic } \\
\text { rate }\end{array}$} \\
\hline & & & & $\begin{array}{c}\text { Aver- } \\
\text { age }\end{array}$ & Range & $\begin{array}{c}\text { Aver- } \\
\text { age }\end{array}$ & Range \\
\hline \multirow{6}{*}{$\begin{array}{l}10 \text { to } 20 \text { per cent below ideal } \\
\text { meight. Average } 123 \text { lbs. } \\
\text { Within } 10 \text { per cent below or } \\
\text { above ideal weight. Aver- } \\
\text { age } 149 \text { lbs............... } \\
10 \text { to } 35 \text { per cent above ideal } \\
\text { weight. Average } 174 \text { lbs. } \\
35 \text { to } 65 \text { per cent above ideal } \\
\text { weight. Average } 214 \text { lbs. }\end{array}$} & & & per & $\begin{array}{c}\text { per } \\
\text { cent }\end{array}$ & per & $\begin{array}{c}\text { per } \\
\text { cent }\end{array}$ & per \\
\hline & 5 & 3 & & $B 0$ & 3 ton & & 10 to 24 \\
\hline & & & & & & & \\
\hline & 19 & 15 & 79 & 6.5 & 1 to 11 & 17 & 5 to 34 \\
\hline & 14 & 10 & 71.5 & 5.5 & 2 to 12 & 15.5 & 7 to 24 \\
\hline & 4 & 2 & 50 & 11.0 & 9.5 to 14 & 16.5 & 11 to 23 \\
\hline
\end{tabular}

sary to attain this drop was almost constant, averaging 6 per cent of the initial body weight. The average loss for the entire period of the diet was 9 to 13 per cent but it must be remembered that the actual loss of weight in pounds was greater in heavier patients. It is apparent that the percentage drop in weight was less than that in the basal metabolic rate, that is, a 6 per cent loss of weight was associated with a drop of 20 per cent in basal metabolic rate.

The loss of weight usually preceded the drop in basal metabolic rate, but in a few cases (e.g., Case 16) even when the patients had been on the diet for some time, the basal metabolic rate fell although little or no weight loss had occurred. This sequence was found especially in patients who were placed on an 800 calorie diet for a second period and is well illustrated by Case 15 (Figure 6). When this patient returned to an 800 calorie diet the basal metabolic rate dropped rapidly to -31 per cent without any loss of weight.

A study of the course of weight loss in our patients is of considerable interest. On this basis they fell into several groups. Most commonly there was a progressive loss of weight from the beginning to the end of the diet (Figure 1). In another large group which included the cases of cardiac failure, the loss in the first week or two was rapid and then became slowly progressive as in the first group (Figures 2, 3, 4, and 6). In several patients, loss of weight ceased after a number of months, although the diet was continued (Figures 2 and 4). Finally, a few pa- tients began to lose weight only after the diet had been in effect one or two weeks. Similarly, when a regular diet was resumed most of the patients gained weight progressively, although in some a lag of one or two weeks was observed (Figure 5 and Case 4, Table I).

\section{Water metabolism}

These variations have been shown to be closely related to the water metabolism of the body (9, 10). The initial loss of weight, usually rapid, is largely the result of a depletion of fluids, as well as of tissue. Later the weight loss, dependent chiefly on depletion of the body tissues, diminishes progressively. On the other hand, the failure to lose weight early, displayed in some cases, is best explained by water retention, a fact that has been emphasized by Newburgh and Johnson (10).

\section{Factor of obesity}

In the three patients weighing 220 to 230 pounds (Cases 40, 41, 42, Table II), the total loss of weight as well as that required to produce a fall in metabolism was almost twice as great as in the less obese group; yet the average percentage drop in metabolism was the same. That is, it was not until 25 to 30 pounds had been lost that the basal metabolic rate began to drop. Only one case (Case 42) in which the patient's weight exceeded 180 pounds gave a reading below -20 per cent. It would seem that in the very obese, there is little need of conserving the excess weight by a reduction in basal metabolism.

\section{Ideal weight}

It might be expected that the basal metabolism would drop only as the ideal weight was approached. In our cases, however, we found no correlation between the two (Table II). Eighteen patients were 10 per cent or more above their ideal weights; in twelve of these, the basal metabolic rate fell significantly long before the ideal weight was approached, particularly in the very obese. Furthermore, in those who eventually attained their ideal weights there was no additional reduction in the basal metabolic rate as the loss of weight continued. Secondly, in four of the group of nineteen patients whose ideal and actual weights approximated each other, the drop in ba- 
sal metabolism was less than 15 per cent. Finally, of five patients 10 to 20 per cent below their ideal weights, the basal metabolic rate dropped less than 15 per cent in two. It is thus apparent that the reduction in basal metabolism occurs irrespective of the ideal weight.

\section{Food requirement for maintenance of weight}

In 14 cases, as a result of repeated changes in diet we were able to investigate a point of considerable theoretical importance, that is, the number of calories required to maintain weight in various stages of activity. Benedict et al. (2) and Muller (11) found that after a restricted diet a considerable diminution in food intake was required to accomplish this end. As a rule, with our patients only 1200 to 1500 calories were necessary to maintain weight when the patient was ambulatory. This subject, however, is being investigated completely, and the results will form a later report.

\section{Explanation of failure of basal metabolism to fall}

As was stated earlier, the basal metabolic rate dropped less than 15 per cent in eleven cases. In most of these a satisfactory explanation could easily be found for this. For instance, if an obese patient did not lose sufficient weight (Cases 33, 38, 40) the basal metabolic rate did not fall significantly. A second important factor proved to be cardiac failure. In other cases the lack of success could be attributed to fever and infection, particularly of the upper respiratory tract (Cases $11,41)$; to frequent attacks of angina pectoris (Cases 3, 6, 33), and to abnormalities of the lungs, such as emphysema and bronchitis (Cases $35,38)$. Several patients impressed us by their hyperthyroid habitus (Cases $3,6,10,26$ ), which perhaps helps to explain our inability to reduce their basal metabolic rates sufficiently.

\section{Effect of heart failure}

- Although, as a rule, we began our readings only after heart failure had disappeared, in some cases we determined the basal metabolic rate in this condition (Cases 23, 31, 33). It was found elevated uniformly, but fell rapidly when the failure was relieved. Case 31, a patient subject to transient attacks of pulmonary edema, illustrates this point (Figure 4). There was little change in his basal metabolic rate for sixty-four days, during which time cardiac failure was present; as this disappeared the basal metabolic rate dropped. Even in patients with heart failure, however, the low calorie diet may effect a drop in basal metabolic rate. For example, Case 23 (Table I) showed persistent moderate left heart failure with a few basal râles, prolonged circulation time and reduced vital capacity. For four weeks, his basal metabolic rate did not fall below zero; then, despite the persistence of the above findings, it gradually dropped from +10 to -10 per cent. In general, the lowest basal metabolic readings were obtained in patients without any evidence of heart failure.

There are numerous references (12) to dyspnea, tachycardia, diastolic hypertension and cyanosis in the literature as factors in heart failure which might be responsible for the elevated basal metabolic rate. Case 5 (Table I) is an example of the effect of cyanosis. Peabody, Meyer and Du Bois (12), Harrison (13), and recently Resnik and Friedman (14) have emphasized the increased muscular effort in dyspnea. The latter authors also pointed out the augmented oxygen consumption of the failing heart, which Starling and Visscher first showed experimentally (15).

\section{Possible ill effect of diet}

The possible ill effects of the prolonged undernutrition to which our patients were subjected were carefully sought for clinically and in the laboratory. We found none. There were no significant changes in the blood sugar which remained above $70 \mathrm{mgm}$. per $100 \mathrm{cc}$., and the serum protein was well within normal limits. Lusk (3) and Rubner (16) had already found a negligible loss of body protein on a diet similar to ours. Because of the intimate relation of the blood cholesterol and basal metabolism in myxedema (17), we made repeated determinations of the former in our patients. There was no definite change from the control figures, irrespective of the diet, drop in the basal metabolic rate and loss of weight. Nor was any alteration in cholesterol obtained by Poindexter and Bruger (18) who treated 30 obese subjects with a low calorie diet.

In no case was ketosis or dehydration en- 
countered although the urine was examined frequently for acetone, and blood counts were done frequently. In fact, there was no demonstrable change for the worse in our patients even after long periods on an 800 to 1200 calorie diet. Eight patients remained on the diet for three to six months, 6 for six to nine months and 2 for nine to twelve months (Cases 39, 42).

\section{Effect of low diet on heart and circulation}

We were especially interested in determining the effect of the low calorie diet on the heart and circulation. An attempt was made to compare

TABLE III

Effect of low calorie diet and low basal metabolic rate on basal pulse rate and blood pressure

\begin{tabular}{|c|c|c|c|c|c|}
\hline Case & Diet & B.M.R. & $\begin{array}{l}\text { Pulse } \\
\text { rate }\end{array}$ & $\begin{array}{l}\text { Systolic } \\
\text { blood } \\
\text { pressure }\end{array}$ & $\begin{array}{l}\text { Diastolic } \\
\text { blood } \\
\text { pressure }\end{array}$ \\
\hline & calories & per cent & $\underset{\substack{\text { per } \\
\text { minute }}}{ }$ & $m m . H g$ & $m m . H g$ \\
\hline 3 & $\stackrel{800}{\text { Regular * }}$ & $\begin{array}{l}-6 \\
-10\end{array}$ & $\begin{array}{l}52 \\
58\end{array}$ & $\begin{array}{c}98 \text { to } 108 \\
146\end{array}$ & $\begin{array}{l}58 \text { to } 66 \\
82\end{array}$ \\
\hline 6 & $\begin{array}{r}800 \\
1500\end{array}$ & $\begin{array}{l}-5 \\
+13\end{array}$ & $\begin{array}{l}60 \text { to } 64 \\
80\end{array}$ & $\begin{array}{l}154 \text { to } 164 \\
174 \text { to } 186\end{array}$ & $\begin{array}{c}76 \text { to } 78 \\
112 \text { to } 116\end{array}$ \\
\hline 12 & $\begin{array}{r}800 \\
1500\end{array}$ & $\begin{array}{l}-10 \\
+2\end{array}$ & $\begin{array}{l}55 \text { to } 62 \\
62 \text { to } 70\end{array}$ & $\begin{array}{l}130 \\
136\end{array}$ & $\begin{array}{l}72 \\
78\end{array}$ \\
\hline 13 & $\begin{array}{r}800 \\
1200 \\
1500\end{array}$ & $\begin{array}{l}-19 \\
-20 \\
-12\end{array}$ & $\begin{array}{l}58 \text { to } 60 \\
58 \text { to } 62 \\
60 \text { to } 68\end{array}$ & $\begin{array}{r}98 \text { to } 108 \\
100 \text { to } 104 \\
102 \text { to } 120\end{array}$ & $\begin{array}{l}70 \text { to } 78 \\
58 \text { to } 68 \\
70 \text { to } 78\end{array}$ \\
\hline 16 & $\begin{array}{r}800 \\
1500\end{array}$ & $\begin{array}{l}-20 \\
-11\end{array}$ & $\begin{array}{l}58 \text { to } 63 \\
54 \text { to } 60\end{array}$ & $\begin{array}{l}126 \text { to } 134 \\
145 \text { to } 150\end{array}$ & $\begin{array}{l}80 \text { to } 82 \\
90\end{array}$ \\
\hline 17 & 800 & $\begin{array}{l}-30 \text { to } 40 \\
-4 \text { to } 7\end{array}$ & $\begin{array}{l}54 \text { to } 60 \\
70 \text { to } 80\end{array}$ & $\begin{array}{r}96 \text { to } 110 \\
126 \text { to } 140\end{array}$ & $\begin{array}{l}64 \text { to } 78 \\
86 \text { to } 90\end{array}$ \\
\hline 18 & $\begin{array}{c}800 \\
\text { Regular }\end{array}$ & $\begin{array}{l}-20 \\
-5\end{array}$ & $\begin{array}{l}48 \text { to } 58 \\
73 \text { to } 80\end{array}$ & $\begin{array}{l}114 \text { to } 126 \\
134\end{array}$ & $\begin{array}{l}76 \text { to } 82 \\
92\end{array}$ \\
\hline 19 & $\begin{array}{l}1200 \\
\text { Regular }\end{array}$ & $\begin{array}{l}-3 \\
+15\end{array}$ & $\begin{array}{l}62 \\
58 \text { to } 68\end{array}$ & $\begin{array}{l}180 \\
218 \text { to } 268\end{array}$ & $\begin{array}{l}100 \\
100 \text { to } 110\end{array}$ \\
\hline 20 & $\begin{array}{r}800 \\
1500\end{array}$ & $\begin{array}{l}-15 \\
+4\end{array}$ & $\begin{array}{l}55 \text { to } 60 \\
68\end{array}$ & $\begin{array}{l}148 \text { to } 158 \\
170\end{array}$ & $\begin{array}{l}80 \text { to } 100 \\
90\end{array}$ \\
\hline 22 & $\begin{array}{c}800 \\
\text { Regular }\end{array}$ & $\begin{array}{l}-20 \\
-1\end{array}$ & $\begin{array}{l}58 \text { to } 60 \\
64 \text { to } 68\end{array}$ & $\begin{array}{r}92 \text { to } 104 \\
112 \text { to } 122\end{array}$ & $\begin{array}{l}66 \text { to } 70 \\
80 \text { to } 88\end{array}$ \\
\hline 25 & $\begin{array}{c}800 \\
1200 \\
\text { Regular }\end{array}$ & $\begin{array}{l}-24 \\
-20 \\
-5\end{array}$ & $\begin{array}{l}48 \\
43 \\
70\end{array}$ & $\begin{array}{l}124 \\
120 \text { to } 130 \\
130 \text { to } 140\end{array}$ & $\begin{array}{l}76 \\
78 \\
80 \text { to } 90\end{array}$ \\
\hline 26 & $\begin{array}{c}1000 \\
\text { Regular }\end{array}$ & $\begin{array}{l}+4 \\
+20\end{array}$ & $\begin{array}{l}60 \text { to } 64 \\
84 \text { to } 92\end{array}$ & $\begin{array}{l}138 \text { to } 140 \\
136 \text { to } 140\end{array}$ & $\begin{array}{l}80 \text { to } 84 \\
80 \text { to } 86\end{array}$ \\
\hline 32 & $\begin{array}{r}800 \\
1500\end{array}$ & $\begin{array}{l}-30 \text { to } 39 \\
-10 \text { to } 26\end{array}$ & $\begin{array}{l}48 \text { to } 52 \\
54 \text { to } 62\end{array}$ & $\begin{array}{l}98 \text { to } 106 \\
90 \text { to } 112\end{array}$ & $\begin{array}{l}70 \text { to } 84 \\
60 \text { to } 75\end{array}$ \\
\hline 39 & $\begin{array}{r}800 \\
1500 \\
2000\end{array}$ & $\begin{array}{c}-20 \\
-9 \\
0\end{array}$ & $\begin{array}{l}44 \text { to } 46 \\
48 \text { to } 56 \\
60\end{array}$ & $\begin{array}{l}130 \text { to } 146 \\
146 \text { to } 162 \\
160\end{array}$ & $\begin{array}{l}90 \text { to } 96 \\
84 \text { to } 90 \\
90\end{array}$ \\
\hline 40 & $\begin{array}{c}800 \\
\text { Regular }\end{array}$ & $\begin{array}{c}0 \\
+23\end{array}$ & $\begin{array}{l}60 \text { to } 68 \\
77 \text { to } 80\end{array}$ & $\begin{array}{l}160 \text { to } 190 \\
180 \text { to } 230\end{array}$ & $\begin{array}{r}90 \text { to } 110 \\
110 \text { to } 120\end{array}$ \\
\hline 41 & $\begin{array}{c}800 \\
\text { Regular }\end{array}$ & $\begin{array}{l}-21 \\
-8\end{array}$ & $\begin{array}{l}56 \text { to } 60 \\
64 \text { to } 68\end{array}$ & $\begin{array}{l}148 \\
148 \text { to } 165\end{array}$ & ${ }_{100}^{84}$ to 106 \\
\hline 42 & $\begin{array}{r}800 \\
2000\end{array}$ & $\begin{array}{l}-22 \\
-3\end{array}$ & $\begin{array}{l}52 \text { to } 56 \\
56\end{array}$ & $\begin{array}{l}136 \text { to } 156 \\
154 \text { to } 176\end{array}$ & $\begin{array}{l}80 \text { to } 90 \\
94 \text { to } 100\end{array}$ \\
\hline Average & $\begin{array}{c}800 \\
1500 \text { to } 2500\end{array}$ & $\begin{array}{c}-16 \\
0\end{array}$ & $\begin{array}{l}56 \\
68\end{array}$ & $\begin{array}{l}132 \\
152\end{array}$ & $\begin{array}{l}81 \\
90\end{array}$ \\
\hline
\end{tabular}

* Approximately 2500 calories. the pulse rate and blood pressure at varying levels of caloric intake and basal metabolism. Obviously, in the cases which had suffered an acute thrombosis, with precipitate changes in the blood pressure and moderate alterations in the pulse rate, only those readings obtained several months after the acute episode had occurred should be considered. This difficulty does not arise in the ambulatory patients with angina pectoris. Seventeen patients were found suitable for such a study; the results of which are presented in Table III. All the readings were taken under basal conditions immediately after the determination of the basal metabolic rate.

It is noteworthy that even in these very seriously ill cardiac patients, the pulse rate on an 800 calorie diet was slow, usually between 50 and 60 beats per minute. In two cases (Cases 25, 39) it fell below 45. An increase in diet effected a rise in pulse rate in most cases. This is well illustrated by Cases $6,17,18,19,25,26,39$, 40. It will be seen that on a regular diet the blood pressure also rose, both the systolic and diastolic pressures being effected. Since the elevation in the former was greater, the pulse pressure as a rule, was increased 10 to $20 \mathrm{~mm}$. We are aware that some of these cases were suffering from essential hypertension in which variations in blood pressure may occur spontaneously. It also may be that the rise in blood pressure in the cases of coronary thrombosis was a delayed consequence of the acute episode. We wish to point out merely that in the cases accepted as suitable, the blood pressure had been stationary for several months on the low calorie diet, and only when the caloric intake was increased, did it rise, sometimes within a week.

\section{Effect of low diet on blood velocity and vital capacity}

The relation of changes in blood velocity and vital capacity to changes in diet and basal metabolic rate is also difficult to estimate in our cases for the reasons given above. However, by careful selection we were able to use eleven patients for such a study (Table IV). The blood velocity, as measured by the saccharin arm-totongue time (19), was determined in nine cases. In eight of these, it remained normal, that is 12 
TABLE IV

Correlation of basal metabolism, blood velocity and vital capacity

\begin{tabular}{|c|c|c|c|c|}
\hline Case & Diet & B.M.R. & $\begin{array}{c}\text { Circulation } \\
\text { time }\end{array}$ & $\begin{array}{c}\text { Vital } \\
\text { capacity }\end{array}$ \\
\hline 4 & $\begin{array}{c}\text { calories } \\
800 \\
1600\end{array}$ & $\begin{array}{c}\text { per cent } \\
-21 \\
-11\end{array}$ & seconds & $\begin{array}{c}c c . \\
3000 \\
3000\end{array}$ \\
\hline 8 & $\begin{array}{r}800 \\
1800\end{array}$ & $\begin{array}{l}-21 \\
-1\end{array}$ & 15 & $\begin{array}{l}2100 \\
2000\end{array}$ \\
\hline 13 & $\begin{array}{r}800 \\
1800\end{array}$ & $\begin{array}{c}-18 \\
0\end{array}$ & $\begin{array}{l}16 \\
16\end{array}$ & $\begin{array}{l}3000 \\
2900\end{array}$ \\
\hline 14 & $\begin{array}{r}800 \\
1500\end{array}$ & $\begin{array}{l}-23 \\
-8\end{array}$ & 12 & \\
\hline 15 & $\begin{array}{r}800 \\
1500 \\
1800\end{array}$ & $\begin{array}{l}-20 \\
-20 \\
-10\end{array}$ & $\begin{array}{l}21 \\
20 \\
17\end{array}$ & 3000 \\
\hline 17 & $\begin{array}{r}800 \\
2500\end{array}$ & $\begin{array}{l}-34 \\
-5\end{array}$ & $\begin{array}{l}15 \\
15\end{array}$ & $\begin{array}{l}4100 \\
4100\end{array}$ \\
\hline 29 & 800 & -19 & 16 & 3200 \\
\hline 30 & $\begin{array}{r}800 \\
1200\end{array}$ & $\begin{array}{l}-19 \\
-9\end{array}$ & 16 & $\begin{array}{l}3400 \\
3600\end{array}$ \\
\hline 32 & 800 & -34 & 16 & 3300 \\
\hline 39 & $\begin{array}{r}800 \\
1000 \\
1500 \\
1800\end{array}$ & $\begin{array}{c}-20 \\
-15 \\
-5 \\
0\end{array}$ & $\begin{array}{l}16 \\
18 \\
14 \\
20\end{array}$ & $\begin{array}{l}3300 \\
3500 \\
3300 \\
3300\end{array}$ \\
\hline 42 & $\begin{array}{r}800 \\
2000\end{array}$ & $\begin{array}{l}-22 \\
-3\end{array}$ & & $\begin{array}{l}3300 \\
3100\end{array}$ \\
\hline
\end{tabular}

to 16 seconds, when the basal metabolic rate had dropped during the period of the low calorie diet. In three of these cases, the readings were repeated when the basal metabolic rate returned to normal; there was no change in circulation time. Hence, it is seen that the blood velocity is perfectly normal in undernutrition in spite of the low basal metabolism. Macy, Claiborne and Hurxthal (20) have also found a normal blood velocity in other types of hypometabolism not associated with myxedema, for example, that seen in hypopituitarism.

The vital capacity was not effected by the lowered basal metabolism (Table IV).

We wish to point out that the majority of the patients considered "failures" or "partial successes" from the standpoint of drop in basal metabolic rate, improved clinically as did the successful cases. Table III shows that some of them also presented beneficial effects on the cardiovascular system. The loss of weight was as great as in the successful cases. To this may be attributed in part the clinical improvement. It is possible that the basal metabolic readings obtained in these cases did not reflect the lowering of total energy expenditure actually present.

\section{DISCUSSION}

Our results indicate that patients with heart disease respond to a low calorie diet (800 calories) as do normal people, i.e. with a drop in basal metabolic rate of 15 to 35 per cent. Several possible criticisms of the validity of our figures must be discussed. Did the state of bed rest in ward patients influence the basal metabolic rate? In the cases of coronary thrombosis could the readings obtained early, while the patient was still suffering from the effects of the acute episode, though no longer acutely ill, be used as controls? Conversely, could the readings obtained after resumption of a regular diet be used as controls? Is an average drop of 15 per cent a significant fall in basal metabolic rate?

We do not believe that bed rest affected the basal metabolic rate appreciably since the low rates persisted after the patient became ambulatory. Also, the basal metabolic rate of patients in bed on a regular diet did not fall significantly.

As to " control " readings, it was often impossible at the beginning to determine the normal basal metabolic rate because of the condition of the patients. In these cases, however, control readings were obtained later when a regular diet was instituted. The control reading was practically the same in whatever period it was obtained. In 13 cases, controls were determined both at the beginning and end of the experiment and all agreed within 5 per cent which is within the limits of error of the method. It would seem then that since the control reading was practically constant, both the early and late readings represent the normal for the patient. Incidentally, the normal readings in most of our cases do not confirm an impression that the basal metabolism in coronary artery disease is low, for in only one case was the reading below -10 per cent.

Finally, we chose a reduction of 15 per cent in basal metabolic rate to designate a successful case, despite the fact that normally the basal metabolic rate lies between +10 to -10 per cent. This normal variation applies, of course, to a group of 
people, whereas in the same person each of a series of readings under similar circumstances will vary little from the average of all readings. Since in this investigation we are dealing with changes in the average of many readings in the same patient, an average reduction of 10 per cent in basal metabolism may be really significant. However, we insisted upon a minimum of 15 per cent as evidence of a significant influence of the diet.

Although this is the first systematic study of patients with cardiac disease treated with a low calorie diet, the influence of undernutrition on the basal metabolism of normal people has been a subject of investigation for many years $(21,22$, $23,24,25,26)$.

Recently DuBois (4), cognizant of the beneficial effect of a low basal metabolism on the heart, expressed the hope that an agent capable of depressing metabolism would be introduced in the treatment of heart disease. A low calorie diet may satisfy this need. As far back as 1900, Hirschfeld (9) had been led by theoretical considerations to conclude that undernutrition lightened the work of the heart. Lusk (3) was aware of the influence of a low basal metabolic rate upon the cardiovascular system and referred to the conclusion of Determan (27) that the reduction of the burden upon the heart and blood vessels which occurs in undernutrition must be beneficial in heart disease. The Karell (28) diet consisting of $800 \mathrm{cc}$. milk daily, has been used in the treatment of cardiac failure for many years. The favorable results obtained with this diet may be attributed not only to the restriction of fluids but to the lowered caloric intake. In the recent German literature there are references (29) to the use of a low calorie diet and small meals in heart disease especially coronary artery disease.

Ample evidence is now available to prove that undernutrition decreases the work of the heart. The latter may be calculated from the formula $W=V P+\frac{m v^{2}}{2 g}(30)$, where $V$ is the minute volume output of the heart and $P$ is the mean arterial pressure. ${ }^{3}$ The minute output is the

3 The second half of the equation is negligible unless the velocity of the blood flow is unusually rapid; $m$ is the mass of blood ejected per minute, $v$ the velocity of blood flow and $g$ the acceleration of gravity. product of stroke volume and heart rate. Since the stroke volume is a function of the pulse pressure (31) and since the mean arterial pressure is practically the arithmetical mean of the systolic and diastolic blood pressures, it is evident that the work of the heart is dependent on the blood pressure and pulse rate. Slowing of the pulse and decrease in blood pressure and pulse pressure produce a reduction in cardiac work. This is exactly what happens in undernutrition. In Benedict's (2) cases on a 1400 calorie diet, the average pressure and pulse rate began to drop at the end of the first week. After three weeks the systolic blood pressure had fallen from an average of 120 to $94 \mathrm{~mm}$., and the diastolic from 83 to $64 \mathrm{~mm}$.; hence, the pulse pressure was diminished from 37 to 30 . The pulse rate was slowed, in some cases, to 35 . Incidentally, the electrocardiograms in these patients were normal. Rubner (16) also found a drop in pulse rate and therefore reduced cardiac work in undernourished persons. Our results show that the influence of a low calorie diet is exerted in patients with cardiac disease as in normal people, with a consequent reduction in the pulse rate and blood pressure.

Slowing of the pulse rate not only lessens the work of the heart but has been shown experimentally to be most efficient for the heart, since less oxygen per unit of time is required for a given amount of work (15). Furthermore, Benedict et al. (2) believed that the fall in pulse rate in his experiments indicated a minimum demand on metabolic activity and that a higher pulse rate in the same individual was usually associated with increased metabolism.

Definite proof of a decrease in the work of the heart as a result of reduction in the basal metabolic rate was recently provided by Altschule (32). Using the Grollman method, he found a pronounced reduction in cardiac output in patients subjected to total thyroidectomy. The cardiac output fell more rapidly than did the oxygen consumption. He concluded that a drop in basal metabolic rate of 30 per cent effected a reduction of 40 per cent in the work of the heart. A similar study was made in Case 17 of our series. The average basal metabolic rate when this patient was on the 800 calorie diet was -34 per cent; the 
cardiac output measured 2.76 liters per minute. When the diet was increased the basal metabolic rate rose to -5 per cent and the cardiac output to 4.15 liters. Hence, the low calorie diet had caused a reduction of 33 per cent in cardiac output. The pulse rate which had averaged 58 on the low diet, rose to 71 ; the systolic blood pressure rose from 96 to $128 \mathrm{~mm}$., and the diastolic from 65 to 86 . Using the formula given above, it was calculated that there was a reduction of 49 per cent in the work of the heart during the low calorie intake.

The reduction in cardiac output in undernutrition is not associated with diminished cardiac efficiency. Benedict (2) studied his subjects carefully from this point of view and subjected them to graduated exercise tests. For short periods of work the percentage increase in pulse rate and blood pressure and also the time required for their return to resting levels, was similar to that for men on a regular diet; and even with more strenuous work there was no discernible modification of the functional efficiency of the heart. As early as 1903, Chittenden (33) studied the effect of excessive muscular exercise on a normal individual who subsisted on a diet of 1700 calories and found no evidence of mental or muscular inefficiency or strain on the heart and lungs. Similarly, Joffe, Poulton and Ryffel (34) by measuring the respiratory exchange after exercise observed no impairment in cardiac efficiency of their patient, a vegetarian who had been on a 300 to 500 calorie diet for three weeks and then on 1000 calories.

Our patients, too, after they recovered from the acute episode, returned to a state of moderate activity. Despite a continued low basal metabolic rate the vital capacity and exercise tolerance did not fall and occasionally improved. The circulation time did not change. Pain was minimal. The obese were distinctly benefited by the increased efficiency of the circulation. It is significant that the output and work of the heart were diminished without any slowing of the blood flow.

The foregoing considerations seem to indicate that a low food intake with its minimal demand on the heart is definitely beneficial. Therefore the use of the low calorie diet in acute heart disease seems logical.

It is interesting to consider the mechanism involved in the drop of basal metabolism in our patients. Lusk (3) had speculated about a diminu- tion in thyroid secretion. However, it is apparent to us that the reduction in our patients was not mediated through the thyroid gland as there were no indications of hypothyroidism in the form of myxedema, rise in blood cholesterol (17) or delay in circulation time (35) even with a basal metabolic rate of -30 or -40 per cent. Indeed, these patients were as alert and efficient at this level as when on a regular diet with a normal basal metabolic rate. We believe with Benedict and Lusk, that the drop in basal metabolism is a protective adaptation of the body to the low calorie intake.

The low calorie diet treatment with the resultant drop in basal metabolic rate and decrease in work of the heart, naturally invites comparison with the procedure of total thyroidectomy which seeks the same objectives. Do we, by undernourishing our patients, attain the same results in the economy of the heart without the risk of a serious and difficult operation? It must be remembered, however, that we have been concerned chiefly with cases of coronary thrombosis, whereas total thyroidectomy (36) has been employed in patients with repeated cardiac failure or intractable angina pectoris. A longer study of our cases of angina pectoris is required before we can judge our results ; with cases of persistent cardiac insufficiency we have had little experience. It is in the acute phase of heart disease, particularly coronary thrombosis, that our method seems most useful. On a low calorie diet some of our patients have been maintained at a level of -20 for six to nine months. This is the level of basal metabolic rate the Boston group (37) has tried to attain by total thyroidectomy. The marked improvement in many of our most seriously ill patients, following the resumption of a diet sufficient to maintain weight, indicates that undernutrition for a period of months may improve the condition of the patient to such an extent that radical measures, such as total thyroidectomy will be unnecessary.

We are most grateful to Dr. Eugene F. DuBois for his keen interest and for his help and many suggestions. Dr. DuBois has encouraged us in this work for a long time.

\section{SUMMARY AND CONCLUSIONS}

1. The effect of a low calorie diet (800 calories) on basal metabolism was studied in twenty- 
eight patients with coronary thrombosis and in fourteen with angina pectoris, whose control basal metabolic rate was within normal limits.

2. In thirty-one patients ( 74 per cent) the basal metabolic rate was lowered 15 to 35 per cent; such a drop was considered significant. In six patients, the basal metabolic rate fell 10 to 14 per cent, and in five, less than 10 per cent.

3. The time required for the basal metabolism to drop was two to four weeks. A similar period was required for its return to normal following the resumption of a regular diet. The body metabolism is determined for several weeks by the previous state of nutrition.

4. Following a period of undernutrition a subsequent period produces a more rapid and profound drop in basal metabolism.

5. The loss of weight necessary to attain a significant fall in basal metabolism averaged 6 per cent of the initial body weight.

6. The following factors tended to prevent a significant fall in basal metabolism; insufficient loss of weight, cardiac failure, upper respiratory infection, and repeated attacks of angina pectoris.

7. No ill effects resulted from the low metabolism induced by prolonged undernutrition of from 3 to 12 months duration. The blood cholesterol, sugar and protein were unaffected.

8. Graduated increases in diet to 1200,1500 and 2000 calories often resulted in corresponding rises in basal metabolism.

9. The drop in basal metabolism is not accompanied by such evidences of hypothyroidism as myxedema, diminished blood velocity and hypercholesterolemia. Vital capacity is not affected.

10. The lowered basal metabolism had a beneficial effect on the cardiovascular system, resulting in slowing of the pulse rate, decrease in blood pressure and pulse pressure and diminution of the cardiac output and work of the heart.

11. A low calorie diet often relieves the symptoms of heart disease.

\section{BIBLIOGRAPHY}

1. Master, A. M., Coronary artery thrombosis with treatment by prolonged rest in bed and low calory diet; Improved prognosis. J. A. M. A., 1935, 105, 337.

2. Benedict, F. G., Miles, W. R., Roth, P., Smith, H. M., Human vitality and efficiency under prolonged re- stricted diet. Carnegie Institute of Washington, Publication No. 280, 1919.

3. Lusk, G., The physiological effect of undernutrition. Physiol. Rev., 1921, 1, 523.

Lusk, G., Science of Nutrition. W. B. Saunders and Co., Philadelphia, 1928, 4th ed., p. 173.

4. DuBois, E. F., Total energy exchange in relation to clinical medicine. Bull. New York Acad. Med., 1933, 9, 680.

5. Master, A. M., Jaffe, H. L., and Dack, S., Low basal metabolic rates obtained by low calorie diets in coronary artery disease. Proc. Soc. Exper. Biol. and Med., 1935, 32, 779.

Master, A. M., Jaffe, H. L., and Dack, S., The basal metabolic rate in a patient with coronary artery thrombosis when placed on an 800 calorie diet. J. Mt. Sinai Hosp., 1935, 1, 263.

6. Strang, J. M., McClugage, H. B., and Brownlee, M. A., Metabolism in undernutrition. Its changes during treatment by high caloric diet. Arch. Int. med., 1935, 55, 958.

Peters, J. P., and Van Slyke, D. D., Quantitative Clinical Chemistry. Vol. I. Interpretations. Williams and Wilkins Co., Baltimore, 1932, p. 36.

7. Anderson, R. J., and Lusk, G., Animal calorimetry. XIII. The interrelation between diet and body condition and the energy production during mechanical work. J. Biol. Chem., 1917, 32, 421.

8. Richardson, H. B., and Mason, E. H., Clinical calorimetry. XXXIII. The effect of fasting in diabetes as compared with a diet designed to replace the foodstuffs oxidized during a fast. J. Biol. Chem., 1923, 57, 587.

9. Hirschfeld, Felix, Die Anwendung der Uberernährung und der Unterernahrung. Frankfurt, a/M. T. Rosenheim, 1897, p. 63. Nahrungsmittel und Ernahrung des Gesunden und Kranken. A. Hirschwald, Berlin, 1900, p. 199.

10. Newburgh, L. H., and Johnson, M. W., The Exchange of Energy between Man and the Environment. C. C. Thomas, Springfield, 1930, p. 84.

11. Muller, F., V. Leyden's Handb. d. Ernährungstherapie und Diätetik. G. Thieme, Leipsig, 1903, 1st ed., p. 195.

12. Peabody, F. W., Meyer, A. L., and DuBois, E. F., Clinical calorimetry. XVI. The basal metabolism of patients with cardiac and renal disease. Arch. Int. Med., 1916, 17, 980.

DuBois, E. F., Basal Metabolism in Health and Disease. Lea and Febiger, Philadelphia, 1924, p. 306.

Boothby, W. M., and Willius, F. A., The basal metabolic rate in cases of primary cardiac disease. $M$. Clin. North America, 1925, 8, 1171.

Lev, M. W., and Hamburger, W. W., Basal metabolism in organic heart disease. Am. Heart J., 1925, $1,240$.

Boas, E. P., and Shapiro, S., Diastolic hypertension with increased basal metabolic rate. J. A. M. A., 1925, 84, 1558. 
13. Harrison, T. R., Failure of the Circulation. William and Wilkins Co., Baltimore, 1935, p. 221.

14. Resnik, Harry, Jr., and Friedman, B., Studies on the mechanism of the increased oxygen consumption in patients with cardiac disease. J. Clin. Invest., 1935, $14,551$.

15. Starling, E. H., and Visscher, M. B., The regulation of the energy output of the heart. J. Physiol., 1926-1927, 62, 243.

Hemingway, A., and Fee, A. R., The relationship between the volume of the heart and its oxygen usage. J. Physiol., 1927, 63, 299.

Harrison, T. R., see (13), p. 90.

16. Rubner, M., Die Physiologische Bedeutung des Stickstoffs. Verhandl. d. ges. deutsch. Naturforsch. u. Arzte, 1921, 86, 81.

17. Hurxthal, L. M., Blood cholesterol and thyroid disease. III. Myxedema and hypercholesteremia. Arch. Int. Med., 1934, 53, 762.

Gilligan, D. R., Volk, M. C., Davis, D., and Blumgart, H. L., Therapeutic effect of total ablation of normal thyroid on congestive heart failure and angina pectoris. VIII. Relationship between serum cholesterol values, basal metabolic rate and clinical aspects of hypothyroidism. Arch. Int. Med., 1934, 54, 746.

18. Poindexter, C. A., and Bruger, M., Effect of low caloric diets and resultant loss in weight on plasma cholesterol in the obese. Arch. Int. Med., 1935, $56,884$.

19. Fishberg, A. M., Hitzig, W. M., and King, F. H., Measurement of the circulation time with saccharin. Proc. Soc. Exper. Biol. and Med., 1933, 30, 651.

20. Macy, J. W., Claiborne, T. S., and Hurxthal, L. M., Blood velocity at varying levels of metabolism in subjects with or without thyroid disease. J. Clin. Invest. (Proc.), 1935, 14, 717.

21. Klemperer, G., Untersuchungen über Stoff wechsel und Ernährung in Krankheiten. Ztschr. f. klin. Med., $1889,16,550$.

22. Pashutin, V. V., Animal and Experimental Pathology. Vol. II. St. Petersburg, 1902, p. 177.

23. Magnus-Levy, A., Der Einfluss von Krankheiten auf den Energiehaushalt im Ruhezustand. Ztschr. f. klin. Med., 1906, 60, 177.

24. Zuntz, N., Einfluss chronischer Unterernährung auf den Stoff wechsel. Biochem. Ztschr., 1913, 55, 341.

25. Loewy, A., and Zuntz, N., Einfluss der Kriegskost auf den Stoff wechsel. Berl. klin. Wchnschr., 1916, 53, 825.

26. Joslin, E. P., Diabetic metabolism with high and low diets. Carnegie Institute of Washington, Publication No. 323, 1923.

27. Determann, H., Die Bedeutung der Kriegsernährung für Stoff wechsel und Gesundheit. Ztschr. f. phys. u. diätet. Therap., 1919, 23, 92 and 137.
28. Karell, P., De la Cure de Lait. Arch. gén. de méd., 1866, 8, 513.

29. Rosin, H., Diät bei Kreislauferkrankungen. Fortschr. d. Therap., 1931, 7, 331.

Kisch, F.: Uber Altes und Neues in der Therapie der Angina Pectoris und des Status Anginosus. Med. Welt., 1932, 29, 1019.

30. Evans, C. L., and Matsuoka, Y., The effect of various mechanical conditions on the gaseous metabolism and efficiency of the mammalian heart. J. Physiol., 1914-15, 49, 378.

Wiggers, C. J., Circulation in Health and Disease. Lea and Febiger, Philadelphia and New York, 1923, $2 d$ ed., p. 136.

31. Erlanger, J., and Hooker, D. R., An experimental study of blood pressure and of pulse pressure in man. Johns Hopkins Hosp. Rep., 1904, 12, 145.

Rosen, I. T., and White, H. L., The relation of pulse pressure to stroke volume. Am. J. Physiol., 1926, 78, 168.

32. Altschule, M. D., and Volk, M. C., The minute volume output and the work of the heart in hypothyroidism. J. Clin. Invest., 1935, 14, 385.

Altschule, M. D., The cardiac output and the work of the heart in hypothyroidism. J. Clin. Invest. (Proc.), 1935, 14, 700.

33. Chittenden, R. H., Physiological economy in nutrition. Pop. Science Monthly, 1903, 63, 123.

Chittenden, R. H., The influence of diet on endurance and general efficiency. Pop. Science Monthly, 1907, 71, 536.

34. Joffe, J., Poulton, E. P., and Ryffel, J. H., The respiratory metabolism in a case of prolonged undernutrition. Quart. J. Med., 1918, 12, 334.

35. Blumgart, H. L., Gargill, S. L., and Gilligan, D. R., Studies on the velocity of blood flow. XIV. The circulation in myxedema with a comparison of the velocity of blood flow in myxedema and thyrotoxicosis. J. Clin. Invest., 1930, 9, 91.

Blumgart, $H$. L., The velocity of blood flow in health and disease. Medicine, 1931, 10, 1.

36. Levine, S. A., Cutler, E. C., and Eppinger, E. C., Thyroidectomy in the treatment of advanced congestive heart failure and angina pectoris. New England J. Med., 1933, 209, 667.

Blumgart, H. L., Levine, S. A., and Berlin, D. D., Congestive heart failure and angina pectoris. The therapeutic effect of thyroidectomy on patients without clinical or pathological evidence of thyroid toxicity. Arch. Int. Med., 1933, 51, 866.

37. Levine, S. A., and Eppinger, E. C., Further experiences with total thyroidectomy in the treatment of intractable heart disease. Am. Heart J., 1935, 10, 736.

Gilligan, D. R., et al. See (17). 